\title{
O fiddle na Música Tradicional Irlandesa
}

The fiddle in Irish Traditional Music

\author{
Autores: ALOÍSIO LEONI SCHMID \\ Departamento de Arquitetura e Urbanismo - UFPR, email: iso@ufpr.br
}

LEANDRO HENRIQUE MERINO MOMBACH

Curso Superior de Tecnologia em Luteria - UFPR, email: mombachhardwood@gmail.com

\section{RESUMO}

o fiddle irlandês, como instrumento musical, é o próprio violino, qual inventado no Norte da Itália no séc. XVI, e popularizado, tendo sido introduzido na Irlanda para tocar prioritariamente músicas de dança nos ritmos da moda do séc. XVII. 0 fiddle recebe hoje uma montagem distinta do violino, que pode repercutir em diferenças de ajuste, acessórios e mesmo no projeto do instrumento. Mas a principal diferença é quanto ao modo de uso, que segue uma tradição oral, com opções estilísticas distintas do violino erudito; um caráter musical em que, além de melódico, é rítmico e por vezes, harmônico; e a finalidade mais de confraternização com dança e contação de histórias, do que exposição do conteúdo musical. A Música Tradicional Irlandesa recebeu adaptações ao longo dos séculos, como os próprios instrumentos, e é hoje popular em muitos países.

Palavras-chave: fiddle; violino; Música Tradicional Irlandesa

\section{ABSTRACT}

The Irish fiddle as a musical instrument is the violin itself, as it was invented in Northern Italy in the 16th century and disseminated, being introduced in Ireland as an instrument supporting dance music in the fashionable rhythms of the 17th century. Nowadays, the fiddle is assemble differently from the violin, which may reflect on the set up, accessories and even the instrument design. However, the main difference concerns the way the instrument is used which follows an oral tradition, with stylish options that differ from those of the violin; the musical character, which is melodic and also rhythmic, and sometimes harmonic; and the purpose that is rather of celebration with dance and storytelling than the exposition of a musical content. The Irish Traditional Music has been changing throughout the centuries, as well as its instruments, and it is popular, nowadays, in many countries.

Keywords: fiddle; violin; Irish Traditional Music 


\section{INTRODUÇÃO}

Se a Música Tradicional Irlandesa tivesse de ser reduzida a um único instrumento, não seria a gaita de foles (uileann pipe), cara e pouco versátil, nem o apito de estanho (tin whistle), acessível, mas estridente. Seria o fiddle. Com a forte disseminação da música irlandesa pelo mundo, a partir dos anos 90, o fiddle acaba sendo um instrumento musical muito popular. Surge a questão inicial, portanto: estamos falando ou não de violino? Outras questões, ainda: como se relacionam o violino erudito e o fiddle irlandês? Quais são as fontes mais apropriadas para entender o fiddle no contexto da Música Tradicional Irlandesa? Como se evita que o apelo comercial descaracterize a tradição?

O objetivo geral desta pesquisa é explorar a delimitação de fiddle no contexto da Música Tradicional Irlandesa. Tal contexto é representado na fotografia "An Irish Fiddler", atribuída a W.A.Green, sem data, reproduzida na Figura 1. A análise se dá a partir de uma perspectiva do violino erudito - inevitável por ser um dos autores luthier, e o outro, violinista amador. Objetivos específicos são o de empreender uma exploração bibliográfica de artigos de orientação musicológica, assim como percorrer de modo não sistemático notas em métodos de Música Tradicional Irlandesa que situem o fiddle e, por fim, analisar de modo não sistemático gravações sonoras e em vídeo de alguns intérpretes de fiddle. Trabalho exploratório, esta pesquisa principia sem uma hipótese.

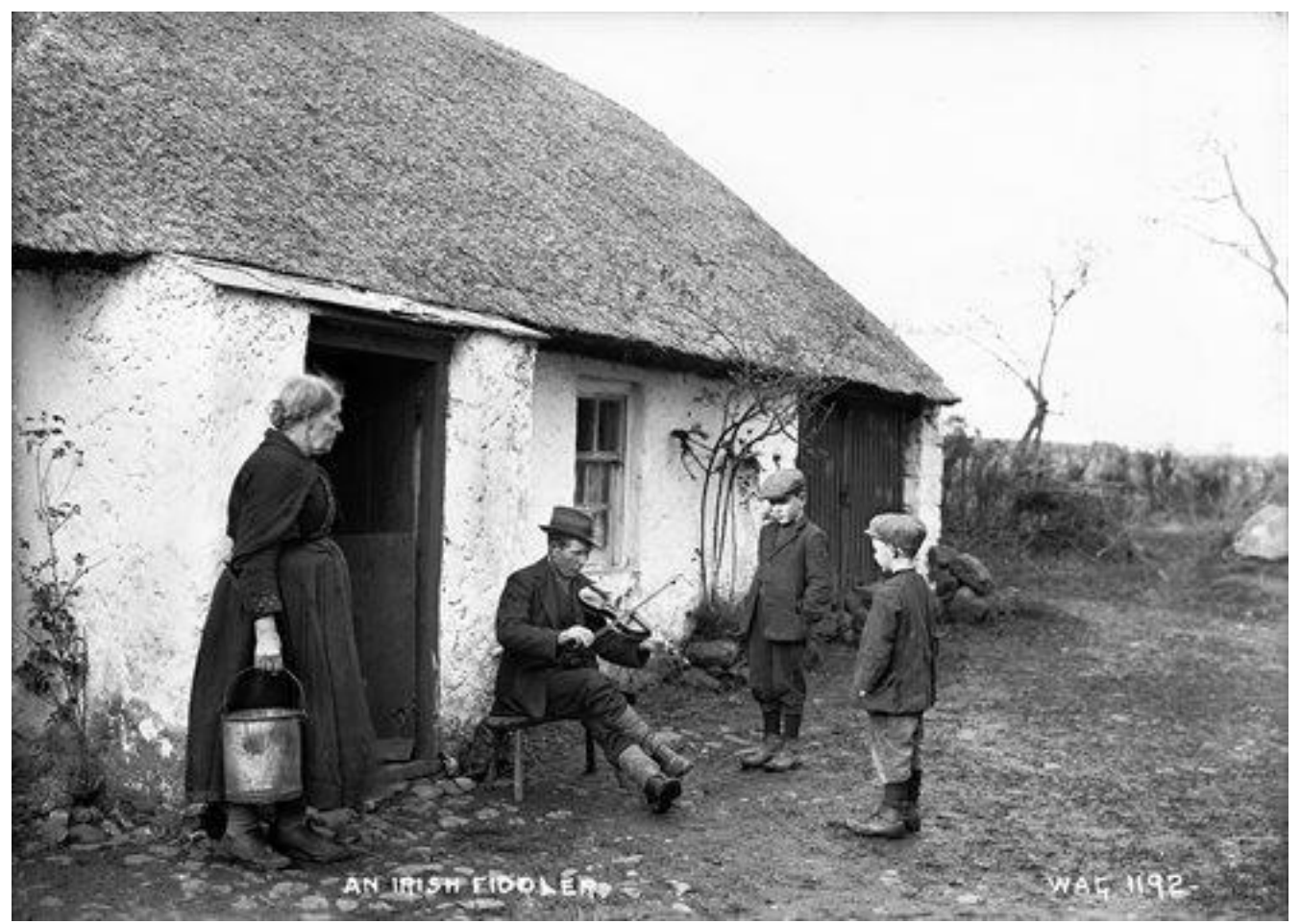

Figura 1 - Um fiddler irlandês. W.A.Green (data desconhecida). Acesso em maio de 2021. Disponível em https://www.nmni.com/collections/history/photographs/green-collection/hoyfmwag1192. CNational Museums NI 


\section{FIDDLE OU O VIOLINO?}

A literatura mostra ser tamanha a variação do que se chama fiddle que parece tarefa mais fácil delimitar violino. Este último tem uma definição que é quase canônica: numa orquestra profissional, não seria provável que um violinista comparecesse portando um instrumento de cinco cordas, tingido na cor azul ou mesmo construído com espécies de madeira outras que abeto e maple. Já fiddle é um conceito de contornos flexíveis. Ainda assim, procuraremos delimitá-lo e em duas etapas: primeiro, com um esclarecimento da origem e evolução do termo; depois, com uma análise pragmática do que, hoje, se chama fiddle no contexto da música irlandesa.

0 termo fiedel é medieval, e discute-se qual seria a referência mais antiga. Uma delas está no baixo-relevo de marfim numa capa de livro do séc. VIII, exposta no museu do Louvre; outra aparece no Livro dos Salmos de Utrecht (860) e também como referência literária em Evangelienharmonie $V$ por Otfried von Weissenburg (BROCKHAUS-RIEMANN, 1990).

Segundo Polk (1989), os termos vedel e geige aparecem em documentos dos séculos XV e XVI, porém descrevendo instrumentos muito diferentes. 0 termo geige parece ter mudado de significado ao longo do séc. XV. 0 autor menciona em documento de 1376, em Duisburg, o termo Meyster Wilhalm dem vedeler (Mestre Wilhalm, o violinista), embora também trouxesse o termo latino citharist em alusão ao mesmo músico. 0 termo fyddelern é mencionado em Frankfurt, em 1368, fiddler em Nuremberg, em 1392, e fiddlers em Aachen, 1383. Na Alemanha, por volta de 1400, registrava-se como instrumentos de corda friccionado o fidle, o rebec e a "viola medieval". o primeiro seria o instrumento com características variáveis, das quais as mais usuais eram "fundo plano e/ou clara distinção entre corpo e braço". A rebec tinha fundo abaulado e a "viola medieval" era um grande fiddle acinturado, e desapareceu ao longo do séc. XIV. O termo germânico vedel era o mais comum até cerca de 1430. Depois ascendeu geige, mais identificado com a rebec. Em algum lugar e momento, ainda aparecem os termos vitula e fitherel.

Em meados do séc. XVII, afirmou-se o significado violino - o instrumento mais possante -, mas permaneceu o significante fiddle. Usa-se hoje o termo fiddle para evocar especificamente o violino qual usado nos estilos musicais country, bluegrass e folk. Paralelamente, é fiddle tudo que se toque com com arco - tanto os violinos de cinco cordas, como os goge de uma corda da África sub-sahariana ou o sarangi indiano (GROVE, 2021), ou o ershu chinês. Coloquial ou carinhosamente, no idioma inglês as pessoas dizem fiddle de seu violino e, em alemão, fiedel. Com mesma função, em português, usa-se o termo rabeca, um modo mais direto de se referir ao violino, e antes, um termo histórico (BERGMANN FILHO 2016; 2021). 
A Figura 2 (fontes no Quadro 1 do Apêndice) é um registro iconográfico do fiddle e similares nos séculos XVI a XIX na Europa e América do Norte. Mostra um instrumento tocado no braço, sustentado pela mão esquerda, e sem ser preso pelo queixo.

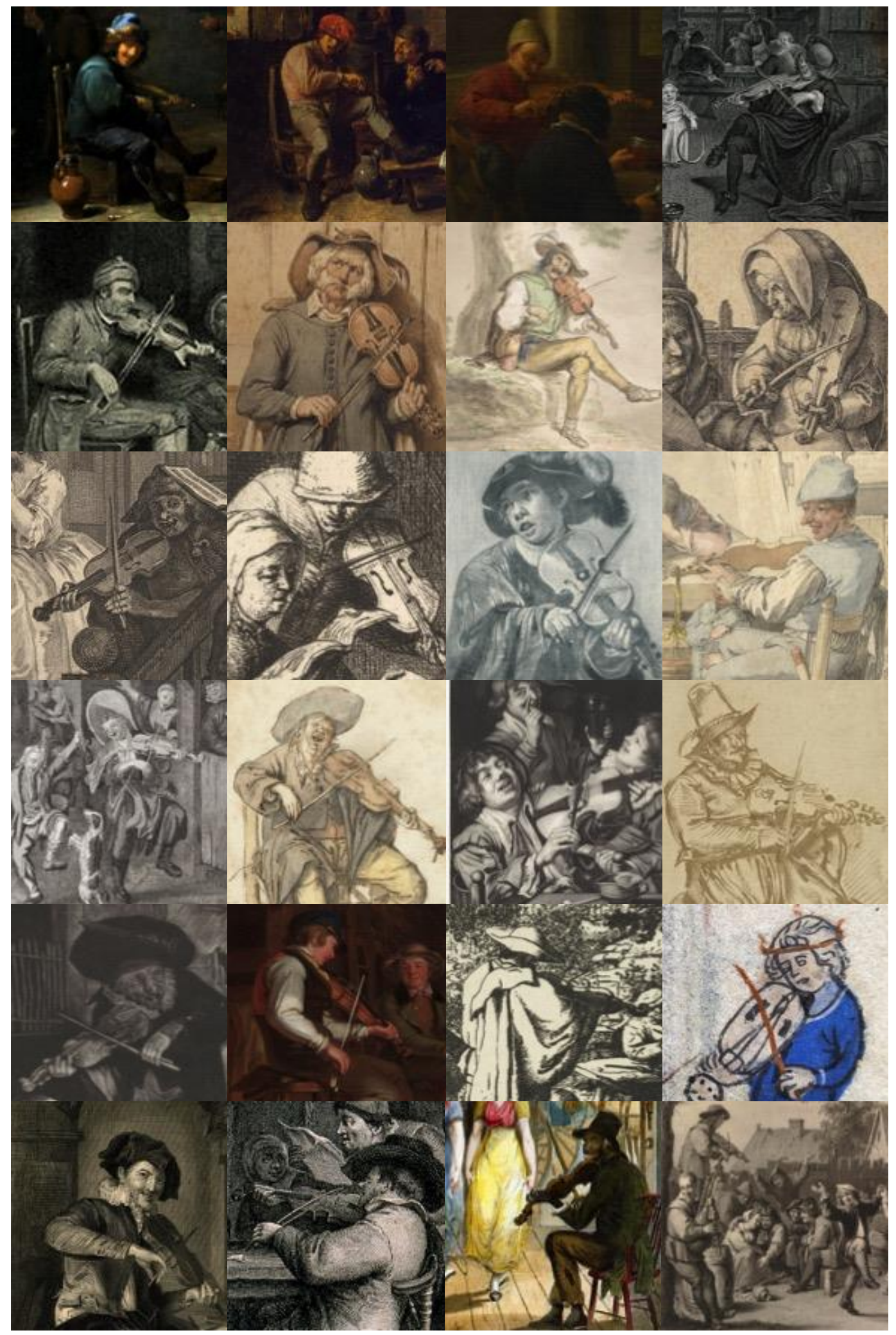

Figura 2 - uma iconografia da postura ao tocar fiddle e assemelhados do séc. XVI ao séc. XIX. Fontes no Quadro 1. 
Tomemos agora o fiddle no contexto atual da Música Tradicional Irlandesa.

Uma primeira diferença em relação ao violino é a preferência por cordas de núcleo de aço. 0 critério para escolha de cordas num instrumento assim pode ser o preço, em geral bem inferior às cordas de tripa ou perlon. Outro é por ser tocado em ambientes mais ruidosos que as salas de concertos dos violinos eruditos.

Há menos exigência de um timbre equilibrado e cheio. Para o fiddle, há acesso facilitado, sem constrangimento, a um microfone ou captador, caso faltem condições acústicas adequada como em bares. Com isto, ainda, o fiddler sozinho conta com a possibilidade de efeitos como reverb (o amplificador emula o efeito de um ambiente mais reverberante, útil em apresentação ao ar livre) ou chorus (o amplificador emula a sensação de mais músicos em uníssono).

Segunda diferença: o violinista prefere a curvatura do cavalete mais arcada e um fiddler, uma mais plana (BERTHOUD 2002, e PERLMAN, 2021). Isto se deve ao fato da tensão da corda de aço ser bastante maior que na corda de perlon, o que facilita o trabalho de um fiddler ao tocar duas ou três cordas simultaneamente. E, pelo mesmo motivo, o cavalete é ajustado para que as cordas fiquem mais próximas do espelho. Este conjunto de medidas faz com que certas técnicas, como mudanças de corda rápidas e acordes, sejam mais administráveis. Seguem, então, outras consequências. Observamos que a pestana também fica mais baixa, saindo em média de 0,35 $\mathrm{mm}$ para cordas de perlon para $0,20 \mathrm{~mm}$, para aliviar a maior tensão na região. Isto também porque a corda, sendo de aço, se deforma menos (a corda lá requer mais pressão de arco para alcançar o nível das vizinhas ré e mi). E voltando ao cavalete: é mais espesso - oscilando conforme a densidade da madeira, a espessura dos pés fica em torno de 4,5 $\mathrm{mm}$ no violino de orquestra e $5 \mathrm{~mm}$ para o violino de corda de aço - para resistir à pressão exercida pelo conjunto das cordas. Partindo dos pés do cavalete, a espessura diminui gradualmente, ficando entre 1,3 e 1,5 mm na extremidade onde as cordas se apoiam. A diferença de pressão exercida entre os tipos de cordas sobre o cavalete faz com que suas perfurações sejam mais abertas nos violinos de orquestra e menos aberta (mais íntegro) para corda de aço.

A alma, que, por baixo do tampo, suporta boa parte de sua tensão, irá mudar mais para perto do cavalete, caso se busque um timbre mais brilhante, metálico, enquanto nos instrumentos de orquestra se preserva o timbre mais doce e amadeirado. Esta diferente montagem acaba exigindo, a rigor, uma diferença estrutural no ângulo do braço do violino. A reta que contém o segmento longitudinal central do espelho (a junção do ponto mais alto de cada seção transversal) até o centro do tampo tem $28 \mathrm{~mm}$ de altura na posição do cavalete. Com cordas de aço, esta altura é reduzida para aliviar a tensão dada pela resultante dos vetores, com 26 e $27 \mathrm{~mm}$ de altura. Finalmente, outra consequência da escolha por cordas de aço é o rabicho mais forte para resistir à tensão mais elevada, recorrendo-se a um fio bem grosso no caso de tripa (como corda de violoncelo de música antiga) ou nylon, ou mesmo um fio metálico. 
A terceira diferença diz respeito aos acessórios. Dada a limitação da técnica, que abre mão dos saltos de posição - como ocorre no violino barroco - são dispensáveis a espaleira e a queixeira. Alguns fiddlers cantam enquanto tocam, e portanto apoiam o instrumento no antebraço, não entre queixo e ombro. Reporta-se o uso de microafinadores. Quanto ao arco, há prováveis diferenças estruturais. Pode-se recorrer a um breu com mais atrito, para vencer a inércia da corda de aço. Não há diferença quanto às cravelhas.

Diante destes fatos, tem-se um instrumento diferente do violino erudito, quase tanto quanto é o violino barroco. São diferenças quanto ao uso efetivo e à identidade do instrumento como representação social, a exemplo do que foi feito para a viola caipira por Schmid et al. (2017). Nesse escopo, Berthoud (2002) é irônico ao mencionar que existem, sim, diferenças físicas: um violino é brilhante e limpo, já o fiddle, pode apresentar resíduos de breu, para não mencionar uma mancha de cerveja e um distinto aroma de fumaça de cigarro).

\subsection{A música irlandesa da antiguidade até meados do século XIX e a presença do fiddle}

Consta no século IV a cristianização da Irlanda por São Patrício (377-461). Nascido na Inglaterra, de família bretã, convertida ao Cristianismo na Inglaterra, aos dezesseis anos foi sequestrado por piratas irlandeses e feito escravo. Fugiu e entrou no mosteiro de Ésir, em Auxerre, na Gália (atual França). Em 432, como bispo, retornou à Irlanda para evangelizar as pessoas. Cahill (1995) relata que soube transmutar as virtudes pagãs de lealdade, coragem e generosidade nos equivalentes cristãos de fé, esperança e caridade. Diz a lenda que usou o trevo para explicar aos pagãos a Santíssima Trindade, o que explicaria ser o trevo símbolo da Irlanda, com a cor verde presente na bandeira. Seu nome em gaélico é Pádraig, nome com que muitos irlandeses são batizados até hoje, com apelido Paddy.

No século VII D.C., segundo o relato de Cusak (1868), viveram na França os evangelizadores S.Fiacre e S.Fursey. A fama dos irlandeses por suas habilidades na música era tão bem conhecida no continente neste período que este último foi convidado por Sta. Gertrudes (628-659), filha do rei Pepino e da abadessa de Nivelle, em Brabant, a lhe enviar os irmãos S.Foillan e S.Ultan, para ensinar música sacra.

Flood (1905) escreveu detalhado relato do princípio da música na Irlanda e relata que, antes de ser estabelecido pelo Papa Gregório o (depois chamado) canto gregoriano, os irlandeses já tinham tablatura, escala diatônica, contraponto e formas musicais. Flood menciona como primeira referência ao fiddle as Lectures do celtólogo Eugene O' Curry (1796-1862), que traduziu do gaélico, um poema sobre a Fada de Carman, no livro de Leinster (hoje na biblioteca do Trinity College, em Dublim). Lá, ao lado de harpa e outros instrumentos de corda, sopro e percussão, menciona o fidil. Mas seria cedo demais; Haigh 
(2021), que menciona o arco mais antigo do século XI, encontrado junto com um fiddle medieval. 0 arco é de dogwood (gênero Cornus), arbusto florido comum na Europa, América do Norte e Ásia, e tem uma cabeça animal entalhada na ponta.

Giraldus Cambrensis, eclesiástico, historiador e escritor (1146 - c. 1223) publicou, em 1187, a Topographia Hibernica (Topografia da Irlanda), em que inicialmente caracteriza o povo da ilha como de hábitos os mais rudes, porém na música incomparavelmente mais habilidosos que qualquer outra nação que eu já tenha visto. Fala em agilidade, doçura e agradabilidade do som, e em proporção e harmonia da música (embora não seja claro, hoje, o significado musical dessas expressões). Afirmou também que a Irlanda usa somente dois instrumentos, a harpa, com cordas de latão ao invés de couro, e o tabor, enquanto que a Escócia usava a harpa, o tambor e o crowd (uma espécie de harpa tocada com arco), e Gales, a harpa, as gaitas (pipes) e o crowd.

Desde o final da Idade Média, a Irlanda se submeteu à dominação estrangeira em três diferentes etapas. Primeiro, os mercenários da Normandia, chamados para auxiliar num combate, acabaram tomando o poder em final do século XIV. Depois, a dominação inglesa: o Rei Henrique VIII foi proclamado em 1541, pelo parlamento irlandês, rei da Irlanda; sua filha com Ana Bolena, Elizabeth I, foi a última da dinastia Tudor. Com sua morte, o trono da Inglaterra foi, em 1603, preenchido pelo rei James I, da Escócia Uacobus em latim), inaugurando o período do chamado Jacobitismo. Era a dominação escocesa.

Neste ponto, podemos diferenciar fiddle de violino, menos como um objeto físico, do que como uma tradição de execução. Desde o final do séc. XVI, início do barroco, a música instrumental com poucos intérpretes, influenciada por Londres e esta, pela Europa Continental, era prática popular na Irlanda, já utilizando o violino italiano, adotado como um fiddle e que se consagrou.

Haigh (2021) associa a popularização do fiddle ao declínio da harpa, instrumento da classe superior da Irlanda, que foi sendo eliminada pelos dominadores. A civilização gaélica sobreviveu entre as pessoas ordinárias, que seguiram falando irlandês (ou gaélico), idioma que se manteve até hoje. 0 confisco de terras tornou a Irlanda um país de grandes propriedades. Ao redor das casas dos proprietários, de religião protestante e leais à coroa, viviam algumas dezenas de pessoas, das famílias dos arrendatários. Aos católicos, era proibida a posse de terras. Usavam técnicas agrícolas inferiores às dos camponeses da Inglaterra e eram mais pobres. Pouco se sabe de suas vidas, além do folclore e das fontes literárias. A economia se manteve principalmente rural, com exceção de Ulster (Irlanda do Norte), industrializada e que no séc. XX seria mantida parte da Grã Bretanha. A população foi aumentando e cresceu a prática da sublocação. Uma relação de certa forma feudal se manteve para dentro da Idade Moderna (BRITANNICA, 2021; ANCESTORNETWORK, 2021). Para Allen e O'Doherty (1985), a limitação material dos camponeses da Irlanda acabou propiciando a preservação de uma música de dança europeia que, em outros lugares, saiu de moda e praticamente se perdeu. 
O fiddle era mais barato e "mais fácil de tocar" e vicejou no meio rural da Irlanda. Segundo Haigh (2021), era tocado solo para dança nas cozinhas de fazendas, ou casamentos, ou feiras, corridas e esquinas. Era prático e funcional. Fiddlers profissionais iriam viajar muitas milhas ao redor de sua cidade, e a tradição era passada de pai para filho.

Em 1674, o eclesiástico e historiador Richard Head (citado por O'HALLMHURAIN, 2017) teria afirmado que "domingo é o dia de mais entretenimento que eles têm, no qual eles usam todas as maneiras de esporte; em cada campo um fiddle, e as senhoras sapateando até não poder mais." 0 editor do guia da APA Publications para a Irlanda, Hoefer (1992), menciona diversos relatos da época sobre a musicalidade da Irlanda; prevalece o que fora observado por um ou outro na Idade Média, e também hoje: o viajante "irá encontrar uma traditional music session num bar ou outro em cada aldeia ou lugarejo, especialmente nos finais de semana; e não será algo preparado para turistas; irá refletir uma tradição musical autêntica que vem de séculos." Mas Hoefer considera exagerada a afirmação de Head, que demandaria a atividade ininterrupta de fábricas de violino.

Contrapomos aqui um entendimento distinto. A população da Irlanda em 1804 era de 5,4 milhões, e havia na ilha de oito a dez mil propriedades rurais.

No final do séc. XVIII, somente de três luthiers de Dublim se tem registrados 7500 fiddles: John Delanius e William Wilkinson, juntos, passaram de 4500 instrumentos, e Thomas Perry ${ }^{1}$ construiu, de 1760 a 1818, mais de 3000 fiddles (CREHAN, 2010). Consta, em 1825, um número máximo de 42 luthiers em Dublim. Por fim, não é razoável julgar que um destes luthiers do século XVII trabalhasse sob o padrão de exigência de um violinista profissional dos dias de hoje. Portanto, há indícios de que havia, de fato, muitos instrumentos na ilha.

Para Smith (1997), a sociedade irlandesa até 1840 era, apesar de pobre, musical, e a música estava presente no tecido da sociedade. 0 fiddler e o uillean piper viviam ocupados em casamentos e velórios, feiras e mercados. A fonte britânica Historyhome (2021) procura desfazer o mito da completa pobreza rural na Irlanda à época anterior à grande fome. Também relata casos de bom relacionamento entre os arrendatários e o senhorio.

Visitantes à Irlanda nos séculos XVIII e XIX, quando a maior parte da música surgiu, relatavam a prática de música e dança (HOEFER, 1992) por que os irlandeses tinham um apetite insaciável segundo Cooper (1995), que menciona "danças de encruzilhada", ao ar livre, no verão, e no inverno a música em cozinhas de fazendas - frequentemente com pouca mobília, e um piso de laje, ideal para a dança.

Segundo Cotaggeology (2021), os chalés (cottages) surgiram ao longo do séc. XVIII com base em técnicas de construção copiadas das big houses. Antes disto, vivia-se em caba-

1 Thomas Perry (1767-1800) foi um renomado luthier de Dublim. Fez muitos violinos com grande habilidade; tom doce e verniz da voluta quase transparente. Copiou em grande parte Amati. 
nas redondas, de wattle and daub (einxaimel), reunidas em comunidade e cercada por um fosso de defesa. Há restos destes assentamentos até hoje. Mas em 1841, 40\% das casas irlandesas eram de terra, de um único cômodo, com chão de terra natural, sem janelas e sem chaminés. Mobiliário e equipamentos de cozinha nessas cabanas eram primitivos (HISTORYHOME, 2021), logo, duplamente desqualificadas para ali acontecer a dança. Portanto, faz sentido a afirmação feita, em 1681, por Thomas Dineley (apud O'HALLMHURAIN, 2017) de que eles estão agora muito viciados (em domingos, depois da gaita de fole, harpa irlandesa e Jews Harpe) a dançar de acordo com suas modas rurais (isto é) a 'long dance', uma depois da outra de todas as condições, senhor, senhora, servos.

Entre 1740-1741, sobreveio uma onda de fome (menos lembrada) que matou cerca de 400 mil pessoas. Mas a conhecida grande onda de fome se iniciou em 1845 e perdurou por pelo menos quatro anos. A batata era a principal fonte de alimentação dos irlandeses mais pobres, seguida da aveia. A cultura de batata foi em grande parte contaminada por um fungo que destruía folhas e tubérculos, chamado blight ou Phylotophthora infestans. Este episódio foi de proporção tal que provocou abalo demográfico, causando a morte de um milhão e a saída de mais de um milhão de irlandeses do país, que emigraram para a Inglaterra, a América do Norte e também a Oceania. 0 romance Trinity, de Leon Uris, disseminou uma ideia do espírito da época, retratando a vida cultural e a luta política entre a grande fome e a conquista da independência. $\mathrm{O}$ autor, americano de origem judaica, casado com uma americana de origem irlandesa, viajou vários meses pela Irlanda em pesquisa para a obra. A pobreza, mas também a vida social, a celebração, alguma coisa que sustentasse uma vontade de viver combinam com a ideia de música e dança.

\subsection{Publicação de música: 300 anos do início tímido até o abran- gente registro da tradição oral}

O'hAllmhurian (2017) relata como da música irlandesa, embora uma arte essencialmente oral, parte encontrou o caminho para as coleções inglesas ainda no séc. XVII. A primeira canção irlandesa a ser publicada foi Cailin ó Chois tSiúri Mé (Eu sou uma garota dos bancos do sul), que aparece no Lute Book (livro para o alaúde) de William Ballet, manuscrito conservado no Trinity College, e no Fitzwilliam Virginal Book. Outras canções aparecem no The Dancing Master), de Playford e no Pills to Purge Melancholy, de D'Urfey, ambos publicados em Londres na segunda metade do séc. XVII. A primeira coletânea exclusiva de música irlandesa, por John e William Neal, a Collection of the Most Celebrated Irish Tunes, 
de 1726, contém, além de algumas árias populares, várias das melodias de Turlough 0'Carolan (1670-1738) ${ }^{2}$. Sobre este conhecido harpista, afirma O’hAllmhurain:

\begin{abstract}
"vivia numa época em que a sociedade irlandesa estava experimentando grande agitação política e religiosa. 0 velho sistema gaélico de patronagem artística estava definhando, enquanto a conversão forçosa ao Protestantismo estava se tornando comum depois da introduão das leis penais no final do séc. XVII. Astutamente cônscio do seu ambiente de trabalho, O'Carolan adaptou seu trabalho para servir ao gosto e status do seu público. Sua música continha uma mistura eclética de melodias irlandesas e não-irlandesas, compostas numa variedade de dialetos, do barroco à música de dança vernaclar. Uma coleção da sua obra foi publicada durante sua própria vida. Como muitos dos seus predecessores, ele "eulogisava" os dois grandes amores de sua vida, mulheres e whisky, em melodias como "Bridget Cruise" e a celebrada "receita para beber". Muito de sua obra barroca foi inspirada por compositores italianos como Corelli e Geminiani e dedicadas a jovens menbros da família Dillon de Lough Glynn e para os Burkes de Glinsk, ambas famílias Normandas com aspirações 'modernas'. Seus planxties (de plearácha, ou peças de louvor) para os MacDermott Roes e os O'Connors de Connacht evocavam um mundo mais velho dos bardos e os duanaire."
\end{abstract}

A coleção dos irmãos Neal é tratada por Dowling (apud WHITE, 2016) como uma transcrição de melodias em que se abandonou a letra original, que sugere a edição "despreocupada em preservar a música antiga". Especulamos se, de fato, chegou a haver letras para os rápidos reels e jigs - é música muito mais no idioma instrumental e dançante do que algo feito para o canto; se a tradição oral era associada ao canto, ou tratava-se mais rigorosamente de uma tradição instrumental, transmitida de memória; e se houve letras, não teriam se perdido no momento da notação? Pois isto se deu nos EUA, por descendentes, e é provavelmente mais fácil escrever música (melodias simples) que escrever letras em gaélico. Para todos os efeitos, Dowling caracteriza o que hoje se denomina música tradicional como um constructo da modernidade, designando o período a partir do colapso da música gaélica no séc. XVIII e da assimilação da música de dança no final do séc. XVII e começo do séc. XVIII. Este argumento coloca em dúvida o termo "música celta" hoje corrente. Para O’hAllmhurain (2017), não há conexões tangíveis com a música dos antigos celtas, senão a música das terras celtas.

Outras publicações do séc. XVIII são mencionadas por O’hAllmhurain (2017): a Aria di Camera de Wright (1730) e a Burke Thumoth Collection (1750). Depois, John Lee publicou duas coleções, em 1774 e 1780, a segunda contendo melodias do gaiteiro Waltker Jackson, de Limerick. A obra Historical Memoirs of the Irish Bards foi publicado por Joseph Cooper Walker, em 1786. Brysson publicou A Curious Selection of Favourite Tunes with Variations, em Edimburgo, contendo 50 árias irlandesas.

Em 1809, aconteceu a segunda edição, revista, da coletânea de música irlandesa de harpa por Edward Bunting, cuja importância é mencionada num artigo por Russell (2006).

2 Há em especial uma composição de 0'Carolan, o "Draught", que se parece em melodia e harmonia com uma bourrée de Georg Friedrich Handel (1685-1759). Ora, este teve notória passagem por Dublin, em que se deu, num salão pouco espaçoso do Fishamble Street, o lançamento do seu oratório Messias. Não temos elementos para afirmar quem copiou quem. 
Na sua introdução, Bunting mostra-se preocupado com uma possível extinção da harpa e explica como isto o motivou à pesquisa, procurando registrar melodias dos mestres Carolan, Conolan e outros já esquecidos. Recorreu a um método que hoje seria chamado "painel de especialistas": promoveu o encontro de dez harpistas da Irlanda, em Belfast, em $12 / 7 / 1792$, e nele anotou o que ouvia. Declara sobre o evento:

\begin{abstract}
"as melodias mais antigas eram, neste respeito, as mais perfeitas, admitindo a adição de um baixo com mais facilidade que as mais novas. Foi observado que seus instrumentos estavam afinados num sistema uniforme, embora os intérpretes fossem ignorantes do princípio. Um motivo principal de convencer tais frágeis remanescentes dos bardos foi procurar cópias mais puras das melodias já nas mãos dos profissionais, e perpetuar uma variedade de outras extremamente antigas, das quais não havia cópias e que eram mais passíveis de ser perdidas; tais finalidades propostas foram parcialmente obtidas pelo encontro mencionado, e foram desde então aprimoradas pelo trabalho do editor."
\end{abstract}

E ainda falando de si afirma:

"Fluente como ele é nas composições das escolas Italianas e Alemãs, ele está convencido que onde o gosto do público for puro, a música original da Irlanda será ouvida com deleite. 0 intérprete irá fazer o favor de lembrar que as velhas melodias de um país e sua linguagem são análogas; que há delicadezas idiomáticas em ambas, para entrar em cujo espírito a prática e a atenção estrita ao tempo de cada área são necessárias, e isto é peculiarmente o caso das composições mais antigas."

Haigh argumenta que as uileann pipes começaram a ser usadas no séc. 18, e eram de status supostamente superior ao fiddle, mas nunca comparáveis em número. A maioria das melodias (tunes) no repertório atual foram escritas para fiddle antes que para gaitas ou mesmo whistles e flautas fossem introduzidas, no séc. 19. Para Haigh, a fome de 1845-49 foi uma oportunidade porque deslocando os irlandeses mais abastados para os EUA, permitiu que lá a cultura do fiddle se fortalecesse encontrando audiência.

Smith (1997) explora duas tendências ocorridas no século XIX depois da grande fome: a estandardização das melodias tradicionais, e a admissão de diferenças regionais na prática da música tradicional - este último fato vinculado à forte redução da população e fechamento de comunidades em si. Afirma, justificando a estandardização, que:

"uma música tradicional, especialmente o produto de uma tradição exclusivamen-
te auditiva, é uma entidade frágil. Sua performance é efêmera, criada para o mo-
mento e desaparecendo imediatamente depois. Sua perserverança depende da
energia e memória dos músicos, seu desejo de ensinar novos músicos, e o interes-
se durador de cada sucessiva geração no valor e continuidade do empreendimen-
to. Num mundo crescentemente sujeito a extinções, tanto biológicas como cultu-
rais, tal ofício para o prazer do momento parece extravagante. A sobrevivência da
tradição musical irlandesa até o dia presente é verdadeiramente milagrosa, pois é
somente uma de muitas formas de música que se nos oferecem de todo o mundo."

Em 1851, foi formada a Society for the Preservation and Publication of the Melodies of Ireland, em parte pelo colecionador George Petrie. Além da fome e do risco de desapare- 
cimento das melodias, havia as atitudes românticas do séc. XIX, que encorajavam a procura pela expressão pura, desinibida de cultura popular. A Gaelic League foi criada em 1893 para promover o idioma irlandês e organizou os primeiros céilidhe - encontros para música, dança e contação de história ao redor do fogo.

Sucedeu a coletânea, publicada em Chicago, pelo superintendente de polícia Francis O'Neill (auxiliado pelo colega James O'Neill), a primeira edição em 1903, e outra em 1907. De acordo com Haigh, são de bastante autenticidade, ao contrário das melodias de Bunting (adaptadas para o piano). Consta que O'Neill se valeu do gravador de cilindro de Thomas Edison para registro, e ao menos um cilindro foi redescoberto em 2003. Apresentou cada tune com o título em inglês e em gaélico. São 1001 danças compreendendo double jigs, single jigs, hop ou slip jigs (compassos ternários), reels (compassos quaternários e andamento em geral muito rápido), hornpipes (quaternários, com a figura de colcheia pontuada), long dances etc.

O próprio autor da compilação explica sobre a origem italiana do jig (nas obras de Veracini e Geminiani). Aceita também a menos compreendida origem italiana dos reel - que são ritmos cuja relação com o continente é bem menos clara. Declarando-se respeitoso da erudição dos cultores tão somente da música antiga e tradicional do país, recomenda no entanto averiguar até que ponto se justifica reivindicar alguma considerável antiguidade para as danças irlandesas e a música para a dança.

\section{A MÚSICA IRLANDESA NOS SÉC. XX E XXI E O QUE É FEITO DO FIDDLE}

A obra de O'Neill retrata um interesse crescente pela Irlanda de fora dela. Stephen Lucius Gwynn escreveu, em 1912, sobre a província de Connaught: lá havia um colégio para o estudo do idioma irlandês que era alternado por festividades: verdadeiros céilidhe. Enquanto que a primeira Guerra Mundial aniquilou a vida rural em boa parte da Europa, a Irlanda pouco foi afetada, tampouco na segunda, e isto contribuiu para a preservação da música tradicional (ALLEN \& O'DOHERTY, 1985).

No séc. XX, nos anos 20, aconteceu nos EUA a gravação em LPs em 78 rpm de música tradicional irlandesa pelos fiddlers Michael Coleman, James Morrison e Paddy Killoran. Tocava-se no estilo sligo (do condado de mesmo nome): altamente ornamentado e expressivo, com acompanhamento de piano ou arranjos com gaitas, banjo, acordeon e flauta. Berthoud (2002) reclama que o destaque dado a tais gravações nos início do séc. XX teria sido indutor de uma uniformização do estilo, diminuindo diferenças regionais. Kearney (2007) fala de uma cultura que não se restringe ao perímetro de uma ilha. Haigh (2021) afirma que as gravações no "estilo New York" começaram a erodir e por fim destruir em grande 
parte o enorme e diverso patchwork de estilos que haviam se desenvolvido Irlanda adentro.

McCullough (1977) observa que estilos da música tradicional irlandesa surgiram de diversas fontes, e que estão continuamente passando por mudanças. Cada estilo é essencialmente uma conglomeração de elementos absorvidos inconscientemente ou apropriados de outros estilos e então reformados e refinados num "novo" estilo "distinto embora nunca inteiramente divorciado de seus predecessores ou contemporâneos." Fala de idiossincrasia e de tradição, com normas estilísticas tácitas. Por fim, se declara a favor da influência das gravações na diversificação de estilos, e afirma:

\footnotetext{
"o estilo na música tradicional irlandesa, embora guiado por certas convenções, não é percebido pelos músicos tradicionais como um conjunto de normas rígido e estático, que deva ser dogmática ou servilmente seguido. É, o oposto disto, um meio flexível, sensível ao contexto, pelo qual a expressão musical de um indivíduo pode ganhar forma e substância que irão investir suas apresentações de valores comunicativos".
}

Se os discos tiveram efeito homogeneizador, acreditamos mais ainda num efeito disseminador, por oferecer a quem escuta um maior leque do que escutaria se tivesse que depender da experiência ao vivo. Isto teria fomentado a consciência da diversidade.

De acordo com Haigh (2021), na Irlanda, na primeira metade do séc. XX, a dança que acontecia nas casas passou a ser formalizada pela Gaelic League, e foi sendo mal vista pela Igreja. A música passou a acontecer nos dance halls e com acompanhamento de piano e uso de outros instrumentos mais eruditos. Registros de então mostram eventos paroquiais, de atmosfera muito diferente dos shows da segunda metade do século XX. A semelhança com suposta instrumentação original era um item menos buscado, mas provavelmente $o$ maior proveito social, com instrumentos acústicos suficientemente potentes para os espaços, ainda na ausência de amplificação eletrônica.

Em 1926, surgiu a rádio estatal da Irlanda (Irish Free State, em 1921) para fomentar o nacionalismo e era muito frequente a apresentação de um trio de fiddle, piano e flauta. A Igreja e o governo lançaram o Dance Halls Act em 1935. Havia a percepção (expressa em 1924 pelo bispo de Galway) da troca das danças nacionais, saudáveis, e importação de danças malignas de Londres, Paris e Nova Iorque.

A música irlandesa experimentou uma derrocada nos anos 40 e 50 com a ascenção do swing e do rock. Um grupo de músicos, preocupados, criou, em 1951, em Dublin, o Comhaltas Ceoltóirí Éireann ("gathering of musicians of Ireland"), ou simplesmente Comhaltas (pronunciado em inglês como key-ol-tas). 0 objetivo desse grupo era instigar um reavivamento da música tradicional irlandesa, promovendo ainda a dança, a linguagem e um senso de comunidade. Estabeleceu-se um festival anual, contendo uma competição nacional, The Fleadh. A ideia se espalhou pela Irlanda e pelo mundo. Novamente, a popularização traz o risco de uniformização. Kearney (2007) destaca a dificuldade do movimento 
se manter longe de política e do nacionalismo, e o consenso mais recente em favor de pacifismo e inclusão. Critica no The Fleadh o desenvolvimento de uma sonoridade Comhaltas por imposição de regras, celebração de certos indivíduos e a imitação de vencedores anteriores.

Nos anos 60, um especial impulso foi recebido do movimento folk nos EUA. A partir deste movimento, Seán Ó Riada, com origem tradicional e formação clássica, cuidando de arranjos com textura e harmonias (quase música de câmera) criou a banda Ceoltóiri Chualann (com os fiddlers Sean Keane, Martin Fay e John Kelly). Foi pioneiro no uso do bodhrán, tambor de moldura originário do séc.XX, a partir de peneiras de grãos (HARTE, 2019). A banda durou pouco, mas abriu caminho para a famosa banda The Chieftains (por que passaram os fiddlers Martin Fay e Sean Keane), que circulou pelo mundo. No final dos anos 60, o folk impulsionou novamente a música irlandesa. A experimentação trouxe acordeão, violão e bouzouki. Surgiram as importantes bandas Planxty (com os fiddlers Tommy Peoples, Paddy Glackin e Kevin Burke), Bothy Band (com Tommy Peoples e Kevin Burke), Altan (com a fiddler Mairéad Ní Mhaonaigh) e De Dannan (com Frankie Gavin, discípulo de Paddy Killoran). Kevin Burke, nos EUA, se aproximou do folk através de Arlo Guthrie, filho de Woody Guthrie, que o convidou para tocar no LP Last of Brooklyn Cowboys; consolidou seu estilo e adotou aquele país para viver. Buscou-se autenticidade, com a admissão de novas influências e da amplificação eletrônica; o que se obteve foi uma nova identidade. É improvável que esta música, que se pretendia tradicional, tivesse soado exatamente assim algum dia.

Calvo-Sotelo (2017) menciona que a música celta estava bem estabelecida no meio dos anos 1970 e já tinha um caráter romântico, naturalista, de uma filosofia altruísta, um progressismo moderado, conotações espirituais e verniz juvenil com claras influências do rock.

Uma terceira onda de popularizacão da música tradicional irlandesa ocorreu então nos anos 90. Era um momento de afluência econômica. Havia algum desencantamento depois da era hippie e da contracultura - as gerações X e Y se mostravam menos beligerantes e mais interessadas na evasão, portanto aceitaram bem o mito celta e sua música como solução para a identidade pessoal e coletiva. Por outro lado, como narra Calvo-Sotelo (2017), a Europa queria competir com a América do Norte e a Ásia. Isto requeria união, e a linguagem seria uma barreira. Faltava, pois, uma explicação étnica para justificar a União Europeia. Sobre que relação têm os dois processos, cabe uma explicação. A Itália, pátria do violino (fiddle nas mãos dos irlandeses), e berço dos jigs, mais uma vez entra em cena. Segundo o mesmo autor, foi decisiva a exposição inaugurada em Veneza, em 1991, (um ano antes do Tratado de Maastricht) chamada I Celti: La prima Europa. Embora construída sobre um argumento historicamente discutível - de etnicidade como base da cultura - obteve pleno êxito. Foi visitada por mais de um milhão de pessoas. Depois de Glasgow), em 1990, Dublin foi designada a capital Europeia da Cultura em 1991. A presidência do conselho da UE fora 
irlandesa), em 1990, e o seria em 1996 e 2004. Alusões à cultura celta foram inseridas em empreendimentos tão diversos quanto novelas, poemas, canções, filmes (Titanic e Braveheart), novas revistas científicas e propagandas de megacorporações (ao som de uileann pipes e fiddle). Calvo-Sotelo relata ainda os parques temáticos Parc Astérix), próximo de Paris, e o Celtworld), em Tramore (Irlanda), como indícios da "celtomania"; foram empreendimentos de curtíssima longevidade; o reavivamento celta perdurou, associado com espiritualidade, artes, música, shows e filmes. Kearney (2007) explica como, nos anos 90, com a expansão da União Europeia, a Irlanda tigre celta passou a ser um destino migratório. 0 país oferece ao mundo alguns clichês comerciais: a empresa aérea Ryanair, que permitiu a milhões de pessoas viajar pela Europa a baixos custos, os duendes (leprechauns) e o "licor global" Bailey's.

Segundo Sotelo-Calvo (2017), depois da exposição de 1991, a música chamada celta se expandiu indefinidamente. A Irlanda foi o país que dela mais se beneficiou, recebendo muitos fundos. Foi criada uma cátedra de música irlandesa na Universidade de Limerick. Nos anos 90, os Chieftains venceram diversos Grammy, depois de terem sido antes somente nomeados. Com eles, Altan, Patrick Cassidy e the Corrs atingiram um pico; artistas irlandeses, em 2003, venderam 56 milhões de álbuns - 2,3\% dos CDs vendidos em todo o mundo. Enya teria sido a primeira artista irlandesa a conquistar popularidade internacional e, em 1994, foi a vez do Riverdance, que tentava desfazer a imagem de uma Irlanda paroquial, com sua lembrança de fome e imigração, para criar uma nova Irlanda, integrada à União Europeia. Musicalmente, calam-se as vozes de protesto e entra o instrumental (sem letra) e de forma diversificada, de modo a ilustrar a diversidade europeia: bodhrán, bouzouki, banjo, castanets, darbuka, harpa, fiddle, gaita de foles, bombarde, tin whistle, hurdy-gurdy, didgeridoo. Sobre este último, observe-se que se trata de um instrumento dos aborígenes da Austrália. Ainda, saxophone, sitar, violoncello, nyckelharpa, além dos instrumentos do rock. As gaitas de fole se tornaram um símbolo: surgiram muitas bandas ao redor de gaitas de fole, e bandas de gaitas de fole. Sugerem antiguidade, raízes europeias e autenticidade. Mencione-se também os festivais, e com destaque o Eurovision. Foi vencido pela Irlanda de 1990 a 1997. No Canadá, a fiddler e dançarina Natalie MacMaster (de Cape Breton) e a cantora Loreena McKennitt tiveram considerável produção nos anos 90. A onda celta chegou na Austrália, e ainda, mesmo que mais fraca, na África do Sul, na América do Sul e no Japão.

Além da Irlanda, os Estados Unidos se destacaram nos negócios viabilizados com a celtomania, e a Irlanda passou a ser vista como extensão do Vale do Silício, senão dos próprios EUA. A Irlanda se coloca no duplo papel de uma extensão dos EUA pelo investimento desse, e um país de terceiro mundo (pela dependência externa). Fagan (2003) relata que, em 2001, a Irlanda havia sido colocada no topo de uma lista referente a globalização. 0 motivo aparente foi uma redução nos impostos sobre empresas, até ocupar a posição dos mais baixos da Europa. Entretanto, o elemento cultural é claramente parte do "tigre celta" e a economia política tem um forte componente cultural. 
Cooper (1995) relata que haviam chegado até então seis mil melodias de dança.

Mas destaca o fato da herança como transformação:

\begin{abstract}
"Conscientemente ou não, intérpretes modificam as melodias de acordo com seu gosto, capacidade e limitações. 0 compositor é esquecido -nomes nos títulos das melodias frequentemente se referem à pessoa de quem a melodia foi aprendida mas a melodia evolui."
\end{abstract}

Fagan (2003) mencionava ser a tradição na música irlandesa sempre inventada seja aquela dos anos 20, como a dos 60 e a dos 90. A primeira, uma reconstrução irlandesa; a segunda, americana, e a terceira, global. E decorridas duas décadas e meia da campanha ambiciosa para reforçar a identidade do continente europeu, Calvo-Sotelo defende a tese de que a ideia da Europa como uma entidade política é profundamente alheia ao espírito celta. Argumenta com a crise grega de 2015, os desdobramentos da política nos continentes e o euro-ceticismo do Reino Unido.

Rapuano (2009) menciona o quanto o musical Riverdance, mesmo sendo pouco autêntico, contribuiu para atrair o interesse internacional, em especial de cidadãos dos EUA, pela música irlandesa tradicional. Trata a procura por identidade nas sessions irlandesas que passaram a prosperar na Irlanda como "em qualquer lugar" e a busca por irishness, caráter irlandês, da parte dos participantes, a maior parte não-irlandeses. Afirmando que tais pessoas nunca se tornarão irlandesas, elas ao menos representam a parte do músico 'irlandês', enquanto mantêm suas outras identificações culturais. A autora expressa a opinião de ser a cultura em que uma pessoa é nascida nunca realmente visível, por óbvia demais, e suas hipóteses parecem autoevidentes; somente através do contraste com outra que a cultura própria se tornaria evidente: como parte de um rito de passagem para comunidade musical, muitos músicos parecem se deixar absorver em mais que música... parecem obcecados com tudo que for conectado com a cultura irlandesa. Manifestações desse comportamento incluem adotar sobrenome irlandês e a narrativa familiar fantástica de um passado nos highlands.

Em síntese, estamos tratando de uma música designada irlandesa, menos por um caráter nativo e mais por sua histórica assimilação na ilha, em que se manteve ao longo das décadas. Somente com relação ao fiddle, neste último episódio de disseminação a partir dos anos 90, não se pode falar que esteve em evidência comercial comparável à dos anos 20: não há evidência de alguma celebridade do fiddle que se faz conhecer fora do contexto de sua banda ou do público da Música Irlandesa Tradicional. É algo diferente o que ocorre no violinio erudito, de que a fama dos solistas parece transcender a popularidade da música em si.

Um último fenômeno a mencionarmos será o da circularidade de influências. Stanton and Schofield (2019) empreenderam um estudo do country britânico como um movimento circular. Habitantes das Ilhas Britânicas emigraram para os Apalaches - em busca de alimento, segurança, oportunidades. Ao partir, não deixaram tudo para trás. Carregaram 
coisas que poderiam lhes trazer conforto e coragem na nova casa. Chamam o fiddle o companheiro de viagem portátil. A prática social dos encontros de fiddlers, os ceilidh, se tornaram reunião no alpendre e rodas de música country. A acentuação sincopada (off-beat), comum entre os fiddlers irlandeses, assim como na canção escocesa, teria agradado as pessoas de origem africana, assim como as escalas incompletas e modos africanos encontraram assemelhados na tradição gaélica. A música country passou a ser chamada como tal (ou hillbilly) em 1965. Por fim agora, séc. XXI, a música country é produzida nas Ilhas Britânicas e alcança enorme popularidade.

Para Stanton and Schofield (2019), pensar a música country de uma perspectiva da herança - enfatizando raízes, origens, mudanças ao longo do tempo, valores e significância pode aprofundar o entendimento de como a música se tornou o que é, mesmo na era comercial, e por que as pessoas continuam a responder a ela positivamente. Em sua pesquisa, que é em parte etnográfica, os autores detectaram que ver prestigiada a sua origem geográfica é uma experiência unanimemente aceita e apreciada. Para os autores, o interesse pela música de outros povos parece motivar a busca pela própria música. Afirmam que a herança musical e sua obra de memória estarão sempre inacabadas. A música country é preservada enquanto é modificada. Na tradição da canção de roda, ninguém tem a última palavra.

\section{ASPECTOS TÉCNICOS E INTERPRETATIVOS DO FIDDLE IR- LANDÊS}

A seguir, empreenderemos uma compilação de características do uso da técnica e da interpretação da Música Tradicional Irlandesa ao fiddle. A análise baseia-se numa relação de artistas selecionados do grupo mais evidente em gravações e filmagens, elaborada e explorada de modo não-sistemático.

Como uma outra fonte de evidência, são exploradas obras didáticas sobre o fiddle irlandês, em notação musical com recomendações textuais - com as limitações naturais de se explicar interpretação mediante texto - por Robinson (1976) e Cooper (1995), e ainda com gravações de apoio como principalmente na obra minuciosa de Berthoud (2002; 2008); as transcrições da obra de Carroll (2011) cujas interpretações da própria música foram aproximadas da melhor maneira em partitura; e ainda a compilação não comentada de Barlow (1977). Neste conjunto, Berthoud é o único a anotar mais detalhadamente ornamentos que utiliza, advertindo seu público para o caráter não rígido de tal prática.

Embora sejam tratados aqui itens específicos de técnica como "arcadas", é difícil separá-los da interpretação, pois, usando as definições de Johansson (2015), há aparentemente mais liberdade na escolha do que fazer (estilo) do que da maneira de fazê-los (técnica). 
O que é idêntico? 0 que é autêntico? 0 que muda e segue mudando, de forma fiel ao original, ao espírito dessa música?

Johansson (2015) explora as relações entre técnica instrumental e estilo musical (que associa a assinatura pessoal e conteúdo). Trata idiossincrasias no manuseio do instrumento (que causam preconceito por muitos professores e acadêmicos). Poderiam a técnica e o estilo ser separados? Como é que tal sinergia ou oposicão informam e restringem o fazer música? Johansson usa a noção de affordances ${ }^{3}$ expressivas do violino, que considera "abertas".

\section{1. $\quad$ Fiddlers abrangidos}

Apresentamos a seguir a relação de fiddlers que constituem base para a análise. É uma amostra não sistemática, arbitrária, a partir da percepção por um dos autores. Tratase de musicistas mais conhecidos e portanto cuja produção é de mais fácil acesso. Cada artista foi considerado mediante registros em áudio, vídeo e também fotografias. É uma abordagem, portanto, fenomenológica.

Michael Coleman (1891-1945): de Sligo, mas radicou-se nos EUA e nos anos 20 realizou gravações muito influentes, muitas vezes acompanhado com piano. Foi um virtuose, fiddle puro.

James Morrison (1893-1947): de Sligo. Soa como um virtuose do violino, embora gravações sejam ruins.

Michael Gorman (1895-1970): de Sligo: outro fiddler antológico uso de dobrados em contratempo (em Mountain Road, influência aparente sobre K.Burke); linha aguda bem constante e presente.

Tommie Potts (1912-1988): de Dublin, mentor de Martin Hayes.

Sean Mc Guire:(1927-2005): de Belfast. Usa arco na metade inferior, som um pouco duro, staccato. Autor de variações virtuosísticas que destoam de modo incômodo do fiddle tradicional.

John Sheahan (1939-): de Dublin, fiddler do renomado conjunto Dubliners. Usa um som firme, cheio, ênfase no apoio à melodia cantada. Tempos moderados. Violino soando junto e ao estilo da uileann pipe.

Seamus Connolly (1944-): de Clare. Possivelmente o mais melodioso dos fiddlers.

30 termo affordance foi cunhado nos anos 70 pelo psicólogo ambiental James Gibson e se tornou um conceito muito usado no campo do Design de produtos. Não há tradução para o português. Affordance é o uso, em interação com o corpo humano, a que o objeto se sugere: numa porta, a maçaneta é para torcer e puxar, a placa para empurrar. Um degrau a $15 \mathrm{~cm}$ de altura é para subir, uma superfície a $45 \mathrm{~cm}$ de altura é para se sentar, uma superfície a $70 \mathrm{~cm}$ de altura alta é para apoiar objetos. 0 que Johansson afirmou foi que há muito mais que se fazer com o violino, a partir do violino, do que fazem os músicos de orquestra. Mas quem estuda violino já encontra um estilo pronto, e procura adquirir a técnica correspondente. 
Sean Keane (1946-): de Drimnagh, tocou nos Chieftains. Virtuose, figurou nos Chieftains até 2002, usando por vezes técnica de violino.

Tommy Peoples (1948-2018): de Donegal, antecessor de Kevin Burke na The Bothy Band: toque original. Som delicado e uso de meigos glissandi associado a triplets (explicação abaixo) rápidos e estalados.

Matt Cranitch (1948-): de Sliabh Luachra, do trio Sliabh Notes, melodioso.

Kevin Burke (1950-): de Londres, de família irlandesa, mas radicado nos EUA desde os anos 70, é considerado herdeiro de Morrison, Coleman e Killoran. Impressiona pelo forte, porém natural apelo rítmico.

Peter Cooper (1951-): de Londres, é autor de método contendo rico material histórico e cultural.

Frankie Gavin (1956-): de Gallway, fiddle numa proposta muito dançante. Uso original de dobrados e tripplets (ver explicação abaixo).

Liz Carroll (1956-): de Chicago. Além de virtuose do fiddle, é uma original e prolífica compositora.

Cathal Hayden (1963-): de Tyrone, virtuose do fiddle e do banjo, fato que se faz notar na força com que utiliza a mão esquerda, e no uso insistente de tripplets, apesar de muito afinado e delicado nos glissandi.

Gilles Apap (1963-): de , Béjaïa, Argélia, é um violinista clássico que também toca música irlandesa e a música popular de outras vertentes.

Eileen Ivers (1965-): de Nova Iorque. Atingiu virtuosismo no fiddle, com técnica semelhante ao violino.

Philip John Berthoud (1966-): de Harare, mas crescido no Reino Unido; autor de método muito detalhado para a assimilação do idioma do fiddle irlandês.

MacDara Ó Raghallaigh (1972-) : de Meath, fiddler que utiliza especial fraseado. Técnica de violino.

Sharon Corr (1970-): de Louth, toca violino simples e eficaz, e faz backing vocal com as irmãs e irmão na banda que tem o nome da família.

Natalie MacMaster (1972-): de Cape Breton (Canadá), dançarina e virtuose do fiddle, com técnica de violino; Fiddle com acompanhamento contemporâneo.

Mairead Nesbitt (1979-): de Tipperary, é conhecida também por atuar no Celtic Women; toca temas tradicionais no violino, com técnica de violino.

Alguns destes musicistas aparecem na Figura 3, que também ilustra a diferença de postura entre fiddlers atuais. Liz Carroll e Martin Hayes usam uma mão esquerda típica do fiddle. Já Kevin Burke e Sharon Corr usam uma mão esquerda típica do violino. Sobre a técnica de arco, não há diferenças a comentar nestas fotos. 

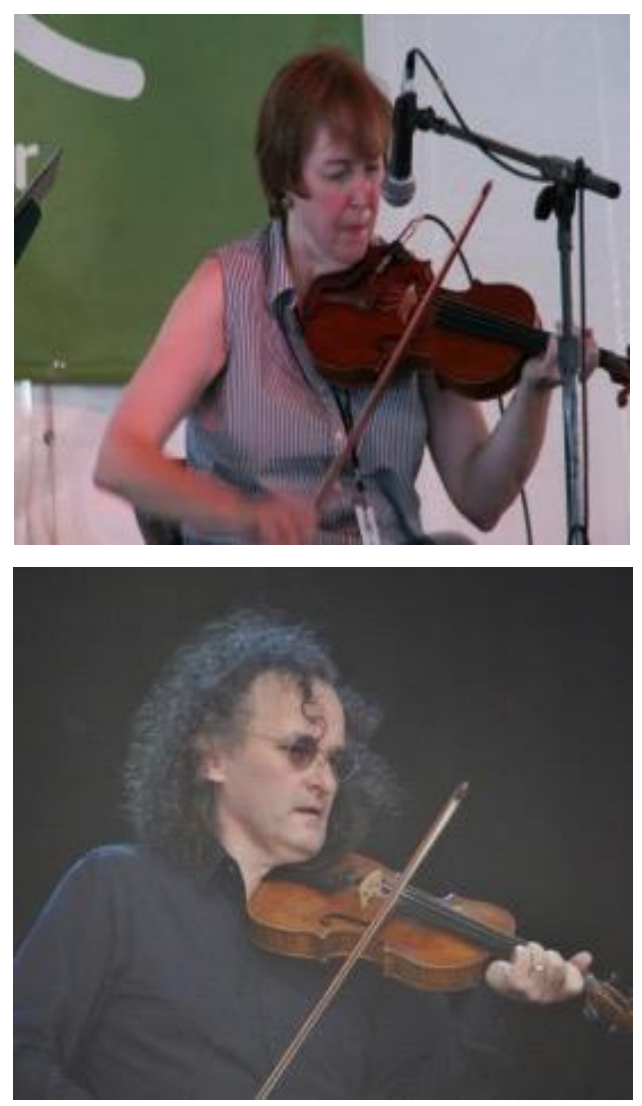

Figura 3 - Na sequência: Liz Carroll (Cindy Funk, 2011, em https://www.flickr.com /photos/cindyfunk/6016266749); Sharon Corr (Tibor Pallerman, 2016, em https:// commons.wikimedia.org/wiki/File:The_Corrs_(Vienna,_2016)_18.jpg) ; Martin Hayes (Michael Coghlan, 2015, em https://www.flickr.com/photos/mikecogh/16271748093/); Kevin Burke (Mark Turner Pictures, 2014, em https://www.flickr.com/photos/thevodkacircle/14173455991/). Todas as fotos foram recortadas.

\subsection{Técnica}

Da relação observada e também da literatura de apoio citada, observaremos atitudes que saltam aos olhos como possibilidades que destoam da técnica de violino. Revelamse em parte do grupo de fiddlers, e em outra não, portanto se mostram, antes, idiossincrasias. São apresentadas no Quadro 2.

A Figura 4 mostra dois fiddlers na Irlanda do Norte, no século XX, registrados por Eamonn O'Doherty em uma pesquisa de campo em Feldman \& Doherty (1985).

Curiosamente, um item usado no fiddle e no violino é a passagem polifônica com sustentação de uma nota mais longa e produção de notas curtas numa corda inferior - recurso usado nas sonatas e partitas para violino solo de Bach, e também com efeitos surpreendentemente rítmicos por Michael Gorman e Kevin Burke em tunes como Mountain Road, College Grooves ou Farewell to Erin. 
Estas listas de itens são produto de um levantamento inicial somente, não exaustivo, mas que acreditamos suficiente para caracterizar uma diferença importante.

QUADRO 02

\begin{tabular}{|c|c|}
\hline Fiddle & Violino \\
\hline ue há certa op & \\
\hline $\begin{array}{l}\text { - apoio da palma da mão esquerda no bra- } \\
\text { ço, e o punho no corpo do instrumento; } \\
\text { - sustentação do instrumento pelo braço, } \\
\text { sem uso do queixo (Figura 3), com conse- } \\
\text { quências: } \\
\text { - instrumento inclinado, caindo para a fren- } \\
\text { te; } \\
\text { - uso quase exclusivo da primeira posição; } \\
\text { - passagem desinibida por cordas soltas; } \\
\text { - uso de dobrados sustentados ou drones } \\
\text { em comparação com os tubos fixos da ui- } \\
\text { leann pipe; } \\
\text { - pressão constante, fazendo-se ouvir as } \\
\text { mudanças de arcada como um guizo. }\end{array}$ & $\begin{array}{l}\text { - pronação (pressão da falange dedo indi- } \\
\text { cador) quando na ponta, e supinação (fei- } \\
\text { ta pelos dedos, em especial o mindinho) } \\
\text { quando no talão; } \\
\text { - mão esquerda em forma convexa, o pul- } \\
\text { so paralelo ao antebraço; } \\
\text { - sustentação do instrumento entre o om- } \\
\text { bro e o queixo (mediante uso de acessó- } \\
\text { rios), permitindo: } \\
\text { - instrumento na horizontal, ou próximo; } \\
\text { - mudanças frequentes de posição; } \\
\text { - prevenção contra cordas soltas e vibrato } \\
\text { frequente; } \\
\text { - notas duplas como sequências melódi- } \\
\text { cas, dedilhadas ou não, em terças, sextas } \\
\text { ou oitavas; } \\
\text { - variação de pressão e suavidade na mu- } \\
\text { dança de corda. }\end{array}$ \\
\hline \multicolumn{2}{|l|}{ outros itens : } \\
\hline $\begin{array}{l}\text { - em grupetos sobre cordas soltas, que exi- } \\
\text { giriam recuar uma corda para tocar a se- } \\
\text { gunda nota: ao invés de 0/1/0/-1/0 usa-se } \\
\text { o desenho 0/3/0/1/0; } \\
\text { - triplets (tercinas em staccato muito rápido } \\
\text { e percussivo como um "tkt"); } \\
\text { - manutenção do arco na corda; } \\
\text { - ligadura levando a notas acentuadas; } \\
\text { - slide (glissando de meio tom subindo em } \\
\text { direção à nota, imitando o canto). }\end{array}$ & $\begin{array}{l}\text { - uso de extensão no dedilhado; } \\
\text { - acordes de três e quatro cordas; } \\
\text { - arco fora da corda: spiccato, collé; } \\
\text { staccato volante e spiccato volante no - } \\
\text { arco subindo e, mais raro, descendo; } \\
\text { - acentuação na ponta (martele); } \\
\text { - glissando, em geral ascendente, em in- } \\
\text { tervalos a partir de segunda maior; } \\
\text { - glissando terminando em harmônico; } \\
\text { - uso de harmônicos soltos ou presos. }\end{array}$ \\
\hline
\end{tabular}

Quadro 2 - diferenças da técnica entre o fiddle e o violino 

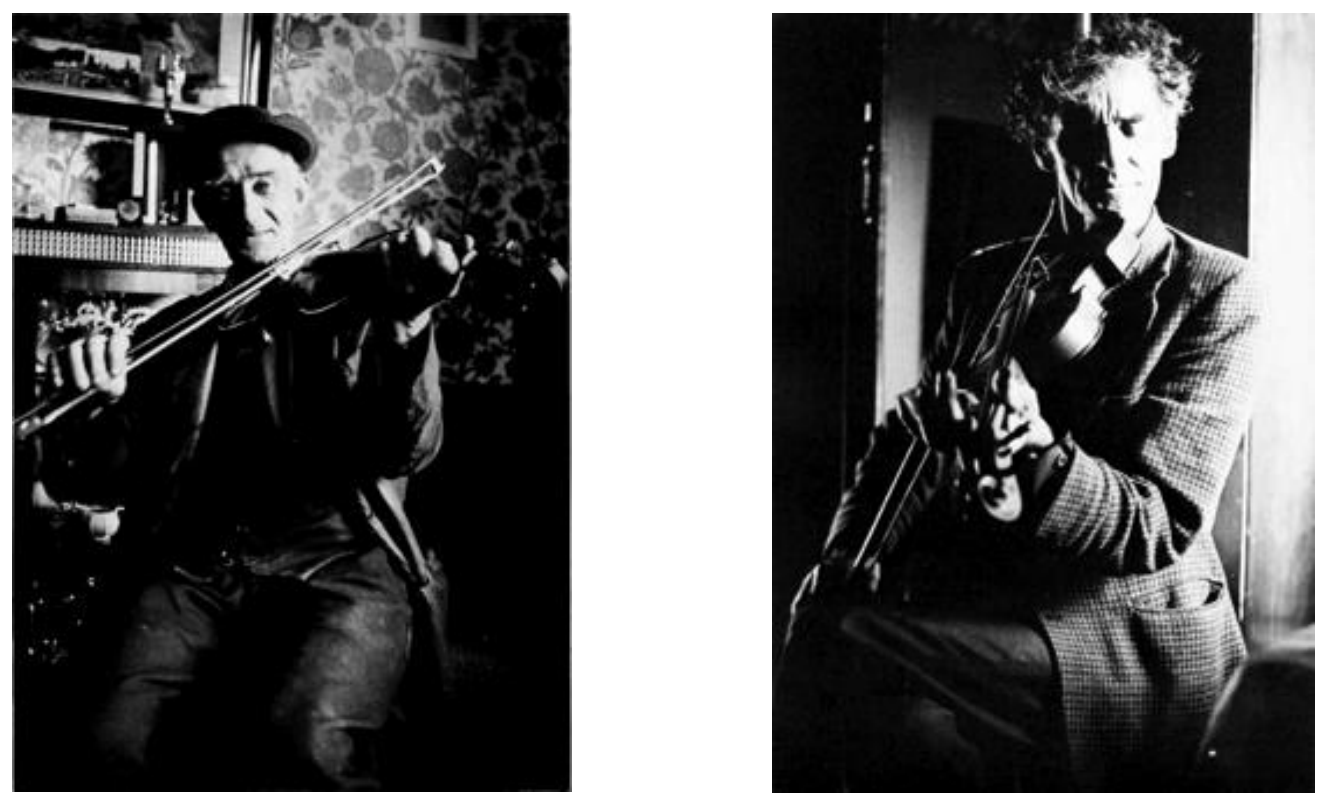

Figura 4 - Esq. Willie Johnson, Lack, County Tyronne e dir., Simon Doherty (1917-1987), Fintown, County Donegal. Fotos por Eamonn O'Doherty em Feldman \& Doherty (1985).

\subsection{Interpretação}

É um tanto difícil, reiteramos, dissociar técnica (como fazer) de interpretação (que efeito obter). Os itens acima relacionados correspondem, a longo prazo, a opções de interpretação que acabam condicionando o desenvolvimento técnico.

Cabe a observação inicial que o fato de se tocar fiddle solo (e não no meio de um naipe de orquestra) confere ao fiddler liberdade, que inclui a escolha e administração do ritmo (em conexão com a dança); a reprodução das melodias, passando pelo número de repetições; e mesmo a afinação, que não é critério eliminatório para se avaliar a musicalidade de um fiddler.

A Música Tradicional Irlandesa é basicamente dançante. Portanto, marca-se de modo sutil, porém obstinado, os tempos fortes, visando à comunicação de um ritmo contagiante, um convite ao movimento corporal. Espera-se do fiddle que seja eficaz em propor uma pulsação ritmada. Mais que isto, que seja eficiente quando se encontra só: de um único instrumentista se obtém um estímulo suficiente. Mesmo amplificado, terá de manter a diferenciação entre os dois níveis de intensidade: sem acento e com acento. Isto já explica muitas das escolhas técnicas acima mencionadas. Não faz sentido acrescer ao toque de fiddle aquilo que não se ouve. Por este motivo, também se usa muito a ornamentação quando nos registros mais agudos, das cordas lá e mi, em que concorre o efeito psicoacústico do mascaramento (identificação preferencial do som mais agudo dentre dois tocados simultaneamente e com mesma intensidade). A partir daqui, porém, falamos de escolhas estilísticas, interpretativas, enfim, artísticas. 
Na Música Tradicional Irlandesa utilizam-se melodias singelas, geralmente com estrutura $\mathrm{AABB}$ ou, menos comum, $\mathrm{AABBCC}$ ou mais longa. Em geral, repete-se toda a sequência.

Trata-se de música modal. Os tunes são facilmente caracterizadas nos modos tradicionais jônio (maior), eólio (menor), dórico, mixolídio. A modulação é raramente utilizada dentro de uma mesma peça; é explorada com moderação por Liz Carroll. Mas ocorre, sim, a modulação intencional entre as diferentes peças justapostas num mesmo set ${ }^{4}$ : tocase em sequencia, duas, três ou (raramente) mais peças de dança, comumente no mesmo ritmo, mas podendo se alternar de jig para reel ou de outra forma. Salta-se normalmente de um tom para sua subdominante. Sendo assim, o que seria a finalização de cada tune serve como tensão para o surgimento do próximo.

Os graus de intensidade como $\boldsymbol{p}, \boldsymbol{m} \boldsymbol{f}, \boldsymbol{f}, \boldsymbol{f} \boldsymbol{f}$ e as variações de dinâmica conhecidas da música erudita - crescendi, diminuendi - não são utilizados. Porém, pontualmente, nas mãos de um Martin Hayes, se mostram um recurso muito expressivo. Usando slow airs como introito, este fiddler se vale da progressiva variação de andamentos, uma espécie de aquecimento gradual em direção à dança.

São recursos interpretativos nas danças rápidas (reels, jigs e polkas):

- $\quad$ arcadas muito rápidas, repetindo aqui a menção aos tripplets, acrescentados como ornamentos nos tempos fracos, como imitando aqueles feitos ao acordeão ou concertina, e não restritos à música irlandesa (curiosamente, são frequentes na música gaúcha);

- $\quad$ arcadas curtas e portanto desprovidas de variações de pressão e velocidade;

- Vibrato em notas selecionadas como opção, mas ausência de vibrato contínuo;

- acento rítmico nos tempo fortes ou, sistematicamente, nos contratempos (caso típico da polka);

- ligadura terminando na cabeça do compasso ou em outra nota acentuada;

- andamentos muito rápidos5;

- mudanças de corda sistemáticas, que fazem com que mesmo sem uso de notas duplas transpareçam duas ou mais vozes, como é usual nas sonatas e partitas de Bach;

- rubato (swing), porém sem prejuízo da pulsão dançante; um estudo de Rosinach e Caroline (2006) constata tal recurso no toque de um músico profissional.

Nas peças mais lentas, como slow airs e hornpipes, é mais evidente a busca por uma pureza de sons, e certa ingenuidade, por vezes prevenindo o uso do vibrato. Aliás, à mão esquerda, mesmo muito hábil, faltam comumente os recursos como do vibrato ou do tocar em outras posições que a primeira.

4 Set é o conjunto de duas, três ou mais danças intercaladas que num recital ou session formam um bloco, sem interrupção.

5 Berthoud (2002), novamente, menciona que os fiddlers seguram o instrumento na frente do corpo, tocam batendo os pés, e ainda "mantêm uma face quase sem expressão enquanto tocam". 
Em ambos os grupos (danças lentas e rápidas), usa-se abundante ornamentação. Esta inclui habitualmente:

- roll (grupeto), do qual já comentamos o caso das cordas soltas;

- cut (apoggiatura superior, por vezes em intervalo de quarta e hammer on (apoggiatura inferior);

- triplets também chamados trebles, já mencionados, mais comum no estilo Donegal (descrito abaixo) e usado por Tommy peoples em reels, mas também em jigs;

- mordentes invertidos (nota principal e a inferior tocadas rapidamente antes da principal);

- $\quad$ slide (glissando) até a nota de interesse, por $1 / 4$ a $1 \frac{1}{2}$ tom ${ }^{6}$;

- cran: é o ornamento feito em ligadura, com o dedilhado 0/2/1/0 na corda solta (HAIGH, 2021) .

Aqui é elucidativa uma comparação com o que ocorre em outros contextos, com outros instrumentos, nos quais as peculiaridades técnicas encaminham opções interpretativas. Um instrumento comum na Europa na época da proliferação das danças era o cravo, que carece do mecanismo de repetição presente nos modernos pianos. Notas rápidas sucessivas não são possíveis, já que a haste vertical chamada saltador de cada nota do cravo sobe, movida pela alavanca da tecla, para seu plectro tanger a corda, e baixa por gravidade, ainda frenado pelo próprio plectro. Esse retorno do conjunto à posição inicial impõe um intervalo mínimo que impede a repetição rápida; mas mordentes, grupetos e trilos são possíveis. Já no fiddle, é possível o triplet já mencionado, e também no acordeão, na concertina, e também nos instrumentos de sopro como whistle e flauta, mediante o estalo da língua por detrás dos dentes.

McCullough (1977) aborda a questão do estilo na música irlandesa, e considera tanto a ornamentação, o uso de variações melódicas e rítmicas do mesmo tema, quanto as diferenças de articulação e fraseado. Propõe a pergunta se é o fraseado que influencia a articulação ou vice-versa.

O uso de ornamentos constitui uma escolha individual de quem se debruça sobre um tune. Ainda, se pode flexionar o modo melódico da peça, criando acidentes musicais; fazendo dos ornamentos notas principais; ligando ou destacando. A ideia de coletânea escrita foi feita, em mais de uma ocasião, para evitar o esquecimento, dado um pessimismo circunstancial; hoje em dia, há diversos métodos impressos para se aprender fiddle. Em se tratando de música tradicional, não há versão correta: uma consequência é o dinamismo, a participação ativa de cada geração no processo, e alguns músicos, apostando na efemeridade da música, desdenham o uso de partitura (BERTHOUD, 2002; HAYES apud COOPER, 2002; SMITH, 1997; REES, 1998, BURKE apud HAIGH, 2021). Pois, num contexto rural, em

6 Cooper (1995) menciona que, se o slide soa vulgar na música clássica, o vibrato soa vulgar na música tradicional. 
que papel, caneta e superfície limpa para escrever não deviam ser recursos abundantes, mais que anotar, se recorria à memória auditiva.

Um violinista, ou instrumentista de solo aprende algo semelhante quando se depara com a música barroca: ao repetir, é obrigação do intérprete variar, oferecer ao público material novo. "Crie. Cause surpresas", afirmou um instrutor de fiddle, Ridley Irish Music School, em Cincinnati (BONA BRIDGE, 2012).

A harmonia é um tema menos lembrado. Sua expressividade é obliterada pelo ritmo e pela melodia, que suetentam o caráter dançante. Seu papel na produção de atmosferas é pobre; vai atrelada, contudo, à produção de versões na melodia principal. Um dos autores desse texto, encontrando-se em 2008, em Dublin, foi comprar um álbum de tunes, e só os encontrou sem acompanhamento. Perguntando ao lojista, este reagiu surpreso: "acompanhamento para quê?" Não explicou exatamente, mas deixou a entender que a harmonia seria óbvia. Na verdade, há um outro motivo: é por não haver regras, senão o propósito de soar bem. Assim também se trata um assunto relacionado à harmonia, que é a batida de violão. Não há regra, mas hábitos mais arraigados. 0 acompanhamento feito ao fiddle por violão introduz cores harmônicas; porém, parece mais preencher vazios do que realçar o ritmo.

Embora se perceba a prática do improviso nas sessions, comuns nos pubs na Irlanda e nos locais de inspiração irlandesa pelo mundo, não é factível o improviso de arcadas ou ornamentos sem intensa experimentação e prática prévias. Dado o uso de pouco comprimento de arco, há margem para se corrigir uma ou outra arcada menos conveniente. Não é algo que se pareça com a organização visual no naipe de cordas de uma orquestra, é antes um compromisso com o fraseado e o ritmo. E não se trata de simples prosódia, algo que torne clara uma melodia: há uma energia pulsante, um convite ao movimento, à dança. Quem escuta Kevin Burke percebe uma espécie de guizo, o atrito residual regularmente cadenciado produzido pelo arco nas mudanças de direção, e tampouco se trata de spiccato.

Numa situação rural e limitada, os camponeses dançavam, numa taverna ou ao ar livre, ao som de um único instrumento: seja o fiddle, uma gaita de foles, um alaúde, uma cornamusa ou outro instrumento de sopro. Este instrumento era responsável por tudo. Há, na Europa, uma profusão de pinturas do séc. XVII (Adrian von Ostade, Adriaen Brouwer, David Tenier, Mattheus van Helmont, Pieter Bruegel, o velho) que retratam esta realidade.

Em termos mais ideais e menos pragmáticos agora, mencionamos acima que geralmente falta o texto cantado que acompanha a música. Todo o material extra-musical ou programático se resume no título do tune. Dificilmente uma peça vem desprovida de título, ou apenas numerada. Os títulos das peças dançantes cobrem uma gama de assuntos comuns na música das diferentes etnias: pessoas, animais, objetos, lugares, partidas, festejos. 0 tema da partida (da Irlanda para a Irlanda) é recorrente. Kevin Burke relata que, em sua adolescência em que aprendia violino clássico, mas frequentava pubs de irlandeses em 
Londres, associou a música de fiddle à "contação de história", que também acontecia, além da dança, nos eventos de confraternização.

Para Johansson (2015), a boa técnica adquirida por exercícios estilisticamente neutros facilita ao estudante de violino poder se concentrar nas características musicalinterpretativas dos diferentes estilos. "Quando a técnica se torna 'natural', ela se move além do controle consciente; ela se torna uma experiência inseparável do que constituem as restrições idiomáticas do instrumento." Mudar de um estilo para outro requer "alternar entre conjuntos de hábitos incorporados." Os conceitos musicais surgem de e são, em última análise, inseparáveis da experiência acumulada de sensações associadas com tocar o instrumento. 0 estilo é em muito decorrência da técnica incorporada.

Já Mark O'Connor, fiddler dos EUA que combina bluegrass, jazz e elementos do violino clássico, afirma ser difícil aprender "pura técnica". Vem junto um estilo. Isto não impede, argumenta, que violinistas se tornem fiddlers ou o contrário, "somente que eles não podem fazer isto simplesmente aplicando suas habilidades técnicas já adquiridas."

Para Swift (2006), hoje os intérpretes com habilidade técnica prodigiosa estão ocupados colaborando além das fronteiras entre violino e fiddle. Mas, segundo o autor, o repertório clássico do violino irá viver para sempre, assim como irá o vasto corpo de tunes que são claramente para o fiddle.

Por fim, Haigh (2021) aborda duas práticas de exotismo no contexto do fiddle irlandês. Uma delas é a scordattura - uso de afinações diferentes do convencional G-D-A-E, subir ou baixar todas as cordas em meio tom, ou afinar diferente mesmo, como AEAE e explorar possibilidades dos drones. Outra é a do violino de estanho, popular em Donegal no início do séc. XX. Era barato, leve e fácil de fazer (poucas horas de trabalho de um latoeiro viajante com prática) e reparar. Braço e espelho eram comumente de madeira. John Doherty era um famoso construtor e usuário.

\section{CONSIDERAÇÕES FINAIS}

Há evidências de que a Música Tradicional Irlandesa, como manifestação cultural, não chegou ao século XXI como herança dos celtas, nem dos habitantes da Irlanda na Idade Média ou mesmo de algum período entre esta e o final do séc. XVII, época das primeiras coletâneas. Tampouco é, hoje, como transcreveram Edward Bunting, ou Frank O'Neill, ou como interpretaram Michael Coleman, os Chieftains ou o Riverdance. É em grande parte a música europeia de dança que, ao menos na França, Reino Unido e Itália, caiu em desuso. Substituída por modismos e aprimoramentos, foi sendo abandonada. Sobreviveu entre os camponeses reprimidos por sua religião, vivendo num regime feudal, à margem da subsistência, numa das ilhas mais remotas da Europa. 
É uma atividade musical e social transmitida oral e organicamente que, em 2021, tem os elementos necessários para se fazer ouvir em 2021, com violinos e violão que têm seu projeto de pelo menos 1900, bodhrán de 1940, uileann pipe e whistles de 1800, e acordeões e concertinas da metade do séc. XIX. A eles se adiciona tecnologia digital e um acesso à informação como nunca antes se viu.

A música feita em cada época é aquela que compele alguém a tomar seu instrumento, senão papel pautado, e fazer, com base no que se conhece, nos instrumentos que se tem, e na sugestão (affordance) do que é bom e, muitas vezes, normal fazer. Fato é, fazia-se música, e a música fazia sentido. E segue. Se hoje vemos o movimento de resgatar fontes históricas para dela extrair traços de interpretação, é porque faz sentido. No futuro pode ser diferente.

Retomamos a definição apresentada no início de que herança é algo que transforma. Enfim redescoberta de seu refúgio temporal-geográfico, a Música Tradicional Irlandesa é manifestação da atividade criativa humana, da cultura, que não estática, mas viva. É um registro de humanidade.

\section{AGRADECIMENTOS}

A Eamonn O'Doherty, através de sua esposa Barbara. A Stephen, do National Museums NI. Ao Irish Traditional Music Archive.

\section{REFERÊNCIAS}

ANCESTORNETWORK, disponível em ancestornetwork.ie/rentals, acesso em 1/5/2021.

BARLOW, Betty M. Fiddle Tunes for the Violinist. 48 pp. Nova Iorque: Amsco (1977).

BERGMANN FILHO, Juarez. Artífices, Artifícios e Artefatos: Narrativas e Trajetórias no Processo de Construção da Rabeca Brasileira.Tese. Curitiba: UFPR/PPGDesign (2016). BERGMANN FILHO, Juarez. Comunicação pessoal. Abril de 2021.

BERTHOUD. Philip John. Irish Fiddle Playing Volume 1. A Guide or the Serious Player. 88 pp. Pacific: Mel Bay (2002).

BERTHOUD. Philip John. Irish Fiddle Playing Volume 2. A Guide or the Serious Player. 110 pp. Pacific: Mel Bay (2008).

BONA BRIDGE, Justin. Comunicação Pessoal. Setembro De 2012.

BRITANNICA.COM acesso e m1/5/2021.

BROCKHAUS-RIEMANN Musik Lexikon. Mainz: Piper-Schott (1990).

BUNTING, Edward. A Collection of the Ancient Music of Ireland. Vol.1 Londres: Clementi \& Co.,(1809), disponível em https://itma.ie, consulta em abril de 2021. 
CAHILL, Thomas. How the Irish Saved Civilization. 246 pp. Londres: Septre Lir (1995).

CAMBRENSIS Giraldus Top ographia Hibernica (1187) Tradução para o inglês como The Topography of Ireland, por Thomas Forester. Cambridge, Ontario: In parentheses Publications (2000).

CALVO-SOTElo, Javier Campos I Celti, La Prima Europa: The Role of Celtic Myth and Celtic Music in the Construction of European Identity. Popular Music and Society, 2017 Vol. 40, No. 4, 369-389.

CARROLL, Liz. Liz Carroll Collected. 102 pp. Chicago: edição da autora (2011). COOPER, Peter. Mel Bay Complete Irish Fiddle Player. Pacific: Mel Bay (1995). COTTAGEOLOGY, https://cottageology.com/irish-cottage-history, acesso em 1/5/2021. CREHAN, Kieran, History of Fiddle Making in Dublin. Filme (2010). Londres: BBC. disponível em https://www.bbc.co.uk/programmes/p007136s.

CUSAK, Mary Frances, e DOYL, Henry. An Illustrated History of Ireland from AD 400 TO 1800. (1868)

DOOLEY, Terence A.M, Estate ownership and management in nineteenth- and early twentieth century Ireland, in T. Dooley, Sources for the History of Landed Estates in Ireland, Dublin, Irish Academic Press, 2000, pp 3-16. (2000).

DOWLING, Martin. Traditional Music and Irish Society: Historical Perspectives. Ashgate, Farnham, Surrey and Burlington, Vt., (2014).

DUBLIN, Dublin Musical Trade, disponível em https://dublinmusictrade.ie/, acesso em $4 / 5 / 2021$.

FAGAN, G. Honor, Globalised Ireland, or, contemporary transformations of national identity? in Coulter and Steve Coleman (org.), The end of Irish history? Critical reflections on the Celtic Tiger. Manchester: Manchester University Press (2003)

FELDMANN, Allen e O'DOHERTY, Eamon. The Northern Fiddler. Music and Musicians of Donegal and Tyrone. 250f. Londres: Oak Publications (1985).

FLOOD, William H. G., A History of Music in Ireland (1905), disponível em https://www.libraryireland.com/IrishMusic/III.php.

GROVE: Grove Music Online. Em https://doi.org/10.1093/gmo/9781561 592630.article.09596, Acesso em agosto de 2021.

GWYNN, Stephen L. e WILLIAMS, Alexander Connaught. Londres: Blackie And Son Limited (1912).

HAIGH, Chris. Fiddling around the world. Disponivel em http://www.fiddlingaround.co.uk/ireland/index.html. Acesso em 29/4/2021.

HARTE, Colin, Bodhráns, Lambegs, \& Musical Craftsmanship in Northern Ireland. Ethnomusicology Forum 2019, VOL. 28, NO. 2, 200-216 (2019).

HISTORYHOME: Disponível em http://www.historyhome.co.uk/ceight/ireland/ireland.htm, acesso em 1/5/2021.

HOEFER, Hans. Ireland. 339 pp. APA Publications (1992). 
JOHANSSON, Mats. On the Relationship Between Technique and Style: the Case of the Violin Music. Education Research, 2015 Vol. 17, No. 2, 127-140.

JOHNSTON, Charles. Ireland Historic and Picturesque (1902). Disponível em https://www.gutenberg.org/files/12078/12078-h/12078-h.htm, acesso em 1/5/2021.

KEARNEY Daithí. Crossing the River: Exploring the Geography of Irish Traditional Music, Journal of the Society for Musicology in Ireland, 3 (2007-8), P. 127.

MCCULLOUGH Lawrence E. Style in Traditional Irish Music. Ethnomusicology, Jan., 1977, Vol. 21, No. 1 (Jan., 1977), Pp. 85-89.

O'HALlMHURAIN, Gearoid, A Short History of Irish Traditional Music. Dublin: O'Brien (2017).

O' NEILL, Francis. 1001. The Dance Music of Ireland. Fac-símile da edição de 1970. 172 pp. Walton's Mfg. Ltd. (1995).

Ó'SÚÍLLEABHAIN, Micheal. Resenha da obra de Martin Dowling, Traditional Music and Irish Society: Historical Perspectives. pp. xvi p 350. Ashgate, Farnham, Surrey and Burlington, 2014 por The Irish Times, 10 de Janeiro (2015).

PEREZ Alfonso; MAESTRE, Esteban; KERSTEN, Stefan; RAMIREZ, Rafael. Expressive Irish Fiddle Performance Model Informed With Bowing, 9th International Conference on Music Perception and Cognition, Bolonha, 2006.

PERLMAN, Itzhak. Em https://Www.masterclass.com/Articles, Acesso em 23/4/2021.

POLK, Keith, Vedel and Geige-Fiddle and Viol: German String Traditions in the Fifteenth Century. Journal Of The American Musicological Society, Vol. 42, No. 3 (1989).

RAPUANO, Deborah, Becoming Irish orBecoming Irish Music? Boundary Construction in Irish Music Communities. J. of American and Comparative Cultures 24(1-2):103 - 113. (2009).

REES , Stephen. Rediscovering The Welsh Fiddle. Strad. Feb98, Vol. 109 Issue 1294, P142. 4p. 2.

ROSINACH, Vincent, TRAUBE, E.. Measuring Swing in Irish Fiddle Music. Caroline, 9th International Conference on Music Perception and Cognition, Bolonha, 2006.

RUSSELL, Joshua A. The Origin and use of an Authentic Irish Folk Tune in American School Orchestra Arrangements. Journal of Historical Research in Music History, XXVIII:1, pp. 38-52 (2006).

SCHMID, Aloísio L.,BERGMANN Filho, Juarez, PEREIRA, Rodrigo Mateus. Em busca da identidade dos instrumentos musicais no Brasil: um estudo exploratório da literatura de cordel. Anais do Museu Paulista: História e Cultura Material (2017).

SKY, Patrick. Ryan's Mammoth Collection - 1050 Reels and Jigs, Hornpipes, Clogs, Walk-Arounds, Essences, Strathspeys, Highlang Flings and Contra Dances, with Figures, and how to play them. Pacific: Mel Bay (1995). 
SMITH, Sally Sommers. The Origin of Style: The Famine and Irish Traditional Music. Éire-Ireland, Volume 32, Number 1, Earrach / Spring (1997), Pp. 121-135 (Article) Published By Irish-American Cultural Institute.

STANTON, Aleen Leigh ; SCHOFIELD, John. 'In The Round': The Circular Heritage of Country Music. Intl. Journal of Heritage Studies: IJHS, 03 October 2019, Vol.25(10), pp.1034-1054.

SWIFT, Learn the Differences Between Violin and Fiddle, Strings Magazine (2006).

VIVA DIFFERENCES. 12 Differences Between Violin and Fiddle. Em https://vivadifferences.com/fiddle-vs-violin/, acesso em junho de 2021.

WHITE, Harry. Resenha da obra de Martin Dowling. Traditional Music and Irish Society: Historical Perspectives, pp. xvi p 350. Ashgate, Farnham, Surrey and Burlington, 2014, em Music \& Letters, $n^{\circ} 1$, pp. 182-185 (2016).

WILLIAMSON, Robin. English, Welsh \& Irish Fiddle Tunes. 96 pp. Nova Iorque: Oak Publications (1976). 


\section{APÊNDICE}

\section{QUADRO 01}

\begin{tabular}{|c|c|c|c|}
\hline $\begin{array}{l}\text { David Teniers, o } \\
\text { mais jovem (1610- } \\
\text { 1690) Fiddler in a } \\
\text { tavern. John and } \\
\text { Mable Ringling Mu- } \\
\text { seum of Art Blue } \\
\text { pencil.svg wikida- } \\
\text { ta:Q612530 } \\
\text { Source/Photographe } \\
\text { rhttp://emuseum.ri } \\
\text { ngling.org/emuseum } \\
\text { /ob }\end{array}$ & $\begin{array}{lr}\text { Adriaen } & \text { Brouwer } \\
(1606-1638), & \text { In een } \\
\text { taverne } & \text { (de } \\
\text { vioolspeler). } & \text { Acervo } \\
\text { do } & \text { museu } \\
\text { Hermitage. } & \text { Domínio } \\
\text { público. } & \end{array}$ & 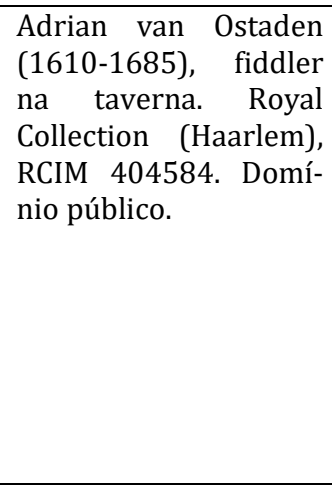 & $\begin{array}{l}\text { Sup., dir. A fiddler plays } \\
\text { in a tavern with a family } \\
\text { drinking at one table and } \\
\text { others in the back- } \\
\text { ground. Gravura por } \\
\text { Ryland a partir de R. } \\
\text { Brakenburg (recorte) } \\
\text { em } \\
\text { https://wellcomeimages } \\
\text {.org/indexplus/obf_ima } \\
\text { ges/03/34/7482cb27a7 } \\
\text { 4b8bd90d75fee5837b.jp } \\
\text { g }\end{array}$ \\
\hline $\begin{array}{l}\text { The blind fiddler. } \\
\text { Pintura por David } \\
\text { Wilkie (National } \\
\text { Gallery or the Tate, } \\
\text { Londres). Gravura } \\
\text { por John Burnet. } \\
\text { Courtesy of the Irish } \\
\text { Traditional Music } \\
\text { Archive. }\end{array}$ & $\begin{array}{l}\text { Meio sup., meio esq. } \\
\text { Fiddle na taverna. } \\
\text { No Metropolitan } \\
\text { Museum, Nova Ior- } \\
\text { que. Met } 832257 . \\
\text { Domínio público. }\end{array}$ & $\begin{array}{l}\text { Anônimo (1858). The } \\
\text { Gipsy Fiddler. The } \\
\text { Metropolitan Museum } \\
\text { of Art, Nova Iorque } \mathrm{N}^{\circ} \text {. } \\
60.620 .57 \text { Domínio } \\
\text { público. }\end{array}$ & $\begin{array}{l}\text { Lucas van Leyden } \\
(1494-1533) \text {. Os músi- } \\
\text { cos. Gravura. The Met- } \\
\text { ropolitan Museum of } \\
\text { Art. n }{ }^{\circ} \text { 59.534.1. Domínio } \\
\text { público. }\end{array}$ \\
\hline $\begin{array}{l}\text { A Rake's Progress. } \\
\text { Gravura por William } \\
\text { Hogarth }(1697- \\
\text { 1764). Metropolitan } \\
\text { Museum , Nova Ior- } \\
\text { que, DP 825211. } \\
\text { Domínio público. }\end{array}$ & $\begin{array}{l}\text { Adriaen van Ostade } \\
(1610-1685) \text { Casal } \\
\text { cantando e violino. } \\
\text { The Metropolitan } \\
\text { Museum of Art, Nova } \\
\text { Iorque. } \\
\mathrm{N}^{\circ} 51.501 .484 \text {. Do- } \\
\text { mínio público. }\end{array}$ & $\begin{array}{l}\text { Violinista. Gravura de } \\
\text { Dirk Koedijck (1908) } \\
\text { baseado em Hendrick } \\
\text { ter Brugghen (1730). } \\
\text { Rijksmuseum, Ams- } \\
\text { terdã N NP-P-1908- } \\
\text { 319. Domínio público. }\end{array}$ & $\begin{array}{l}\text { Pieter Moninckx (1616- } \\
\text { 1686). Interior com vio- } \\
\text { linista, mulher dormin- } \\
\text { do e cachorro dançando. } \\
\text { Desenho. Rijksmuseum, } \\
\text { Amsterdã. N }{ }^{\circ} \text { RP-T- } \\
\text { 1911-85. Domínio pú- } \\
\text { blico. }\end{array}$ \\
\hline $\begin{array}{l}\text { Músicos de rua. Gra- } \\
\text { vura de anônimo } \\
(1830-1887) \text {, basea- } \\
\text { do em Cornelis Du- } \\
\text { sart Rijksmuseum, } \\
\text { Amsterdã. N }{ }^{\circ} \text { RP-P- } \\
\text { 1887-A-12260. Do- } \\
\text { mínio público. }\end{array}$ & $\begin{array}{l}\text { Jan Havicksz, An- } \\
\text { tuérpia } \quad(1636 \quad- \\
\text { 1679). Violinista } \\
\text { cantando. Rijksmu- } \\
\text { seum, Amsterdã. N. } \\
\text { RP-T-1879-A-9. Do- } \\
\text { mínio público. }\end{array}$ & $\begin{array}{l}\text { Jacob Gole (1670- } \\
\text { 1724). Jovem violinis- } \\
\text { ta sentado e outros } \\
\text { dois, e um cachimbo. } \\
\text { Gravura. Rijksmu- } \\
\begin{array}{l}\text { seum, Amsterdã. RP-P- } \\
\text { 2001-40. Domínio } \\
\text { público. }\end{array}\end{array}$ & $\begin{array}{l}\text { Willem } r \text { Pietersz. } \\
\text { Buytewech. Violinista } \\
\text { sentado (1620-1624). } \\
\text { Rijksmuseum, Amsterdã, } \\
n^{\circ} \text { : RP-T-1884-A-296. } \\
\text { Domínio público }\end{array}$ \\
\hline $\begin{array}{l}\text { Músico e um homem } \\
\text { que oferece fumo. } \\
\text { Gravura de anônimo } \\
\text { (1905) baseada em } \\
\text { Cornelis Dusart, } \\
\text { pintura de } 1685 . \\
\text { Rijksmuseum, Ams- } \\
\text { terdã. N }{ }^{\circ} \text { RP-P-1906- } \\
3084 \text {. Domínio pú- } \\
\text { blico. }\end{array}$ & $\begin{array}{lr}\text { William } & \text { Sidney } \\
\text { Mount: The Power of } \\
\text { Music. } & \text { Cleveland } \\
\text { Museum of Art } & \text { of Án } \\
\begin{array}{l}\text { 1991.110. Domínio } \\
\text { público. }\end{array}\end{array}$ & $\begin{array}{l}\text { Anônimo (1657-1745) } \\
\text { a partir de Adrian von } \\
\text { Ostaden. Vioolspeler } \\
\text { en een jonge } \\
\text { lierdraaier. Gravura. n } \\
\text { RP-P-1909-4129, Ri- } \\
\text { jksmuseum (Amster- } \\
\text { dã). Domínio público. }\end{array}$ & $\begin{array}{l}\text { Anonymous (Huy, Bélgi- } \\
\text { ca). Folha do Livro das } \\
\text { Horas. Walters Art Mu- } \\
\text { seum, Baltimore, Núme- } \\
\text { ro W.37.21R. Domínio } \\
\text { público. }\end{array}$ \\
\hline $\begin{array}{lr}\text { Allan Cunningham, } \\
\text { gravura por Henry } \\
\text { Chawner } & \text { Shenton. } \\
\text { 1833.The } & \text { Merry } \\
\text { Fiddler. British Mu- } \\
\text { seum. } \\
\begin{array}{l}\text { 3224477. Objeto } \\
\text { público. }\end{array}\end{array}$ & $\begin{array}{l}\text { J. Heudelot (fim do } \\
\text { séc. XVIII). Gravura } \\
\text { baseada em Adrian } \\
\text { von Oestede (1610- } \\
\text { 1685). Domínio pú- } \\
\text { blico. em } \\
\text { https://wellcomecol } \\
\text { lec- } \\
\text { tion.org/works/x68 } \\
\text { 4ah62 }\end{array}$ & $\begin{array}{l}\text { Pavel Petrovich } \\
\text { Svinyin (1787-1839) } \\
\text { Festança num restau- } \\
\text { rante em Wayside } \\
\text { (cerca de 1818). Publi- } \\
\text { cado no Voyage Pitto- } \\
\text { resque Aux Etats-Unis } \\
\text { de l'Amérique. Domí- } \\
\text { nio público. }\end{array}$ & $\begin{array}{l}\text { David Tenier, o mais } \\
\text { jovem. Casamento de } \\
\text { camponeses. Litografia } \\
\text { de } 1836 \text {. British Mu- } \\
\text { seum. } \mathrm{N}^{\circ} 1852,1009.455 . \\
\text { Domínio público. }\end{array}$ \\
\hline
\end{tabular}

Quadro 1 - fontes da Figura 3. 